Fecha de recepción: diciembre 2017 Fecha de aceptación: marzo 2018 Versión final: julio 2019

\section{Memórias das Missões em Pinturas de Aldo Locatelli: Analisando representações de santos missionários dos séculos XVI e XIX em igrejas católicas do Rio Grande do Sul (1952-1962)}

Anna Paula Boneberg Nascimento dos Santos *

\begin{abstract}
Resumo: Ao desembarcar no Brasil em 1948, o figurista italiano Aldo Daniele Locatelli trouxe consigo mais do que um visado histórico de formação na renomada Escola de Artes Andrea Fantoni: Suas pinturas em igrejas europeias já projetavam a sua fama, despertando o interesse de altos exponentes do clero católico. Pode-se afirmar, contudo, que ainda inexistem estudos publicados sobre este pintor que contenham um aprofundamento significativo das temáticas reproduzidas em igrejas do Rio Grande do Sul, onde se encontra a maior profusão de suas obras sacras. As pinturas tematizadas nas missões católicas do século XVI e em personagens destacados pela sua atuação neste período ou por uma evangelização a posteriori concatenada aos seus preceitos conferem a abordagem deste artigo, numa análise temática e técnica que reflete o contexto de feitura de dois murais integrantes das ambiências da igreja Santa Teresinha do Menino Jesus de Porto Alegre (1952-1957) e da catedral São Luiz Gonzaga de Novo Hamburgo (1959-1962). Quando consideradas como fontes, as imagens deixam de possuir função meramente ilustrativa e passam a compor parte do corpus documental de uma pesquisa. Concordando com esta premissa, Ivan Gaskell considera que "alguns historiadores têm proporcionado valiosas contribuições à nossa visão do passado usando as imagens de uma forma sofisticada e especificamente histórica”. (GASKELL, 2011). É neste sentido que as imagens representativas de Santa Teresa D’Ávila, São Francisco Xavier, São Luiz Gonzaga e Santa Teresinha do Menino Jesus permitem uma reflexão acerca da importância que o catolicismo conferiu à perpetuação das memórias de religiosos missionários através das artes visuais.
\end{abstract}

Palavras chave: Aldo Locatelli - Pintura Sacra - Catolicismo - Memória - Santos Missionários.

[Resumos em espanhol e inglês nas páginas 77-78]

${ }^{(*)}$ Doutoranda em História pela Universidade do Vale do Rio dos Sinos (UNISINOS), com bolsa vigente da Coordenação de Aperfeiçoamento de Pessoal de Nível Superior (CAPES/ PROSUC). Pesquisadora no Instituto Cultural Emilio Sessa (ICES). 


\section{Construindo o cenário temático em breves notas}

Toda pesquisa requer tempo, disto, sabe-se. É necessário tempo para coletar as fontes adequadas... E, mais tempo, para selecioná-las. Algum tempo para organizar e cotejar todo o material, de documentos a bibliografias sobre o objeto investigado... E um tempo ainda maior para a escrita, para a sistematização de algumas ideias que permitam ao próprio pesquisador compreender os resultados que puderam ser angariados, de modo que eles, talvez, façam sentido também aos seus pares e/ou àqueles a quem suas conclusões se destinam. Em História, sobretudo quando as fontes remetem ao passado de comunidades contemporâneas a quem as estuda, há ainda outra questão temporal que deve ser considerada e que consiste na facilitação do acesso aos resultados obtidos pelos seus herdeiros, ou seja, por aqueles a quem as suas guardas foram destinadas. Isto nem sempre é fácil, uma vez que o tempo traz consigo mudanças de concepções acerca da importância daquilo que "já não está". Este é, certamente, um problema que atravessa os estudos das imagens e, no caso desta pesquisa, acentua-se pelo fato de que as fontes iconográficas examinadas destacam personagens de séculos anteriores ao do seu público. Que mensagem a Igreja Católica pretende transmitir aos evangelizadores -clérigos e leigos- do século XX, ao inserir em seus templos representações dos primeiros santos missionários do século XVI e, ainda, de seus seguidores do XIX? Esta é uma das questões que busco responder, tendo como ponto de partida a contratação de um pintor italiano para a decoração de igrejas no Rio Grande do Sul.

Se considerado o tempo transcorrido desde as primeiras análises temáticas que fiz de pinturas sacras em igrejas católicas do Rio Grande do Sul, posso dizer que esta pesquisa remonta há pouco mais de uma década. O seu enfoque no tema da missionação é, contudo, bastante recente e está no estágio que aqui relacionei como "tempo para organizar e cotejar". Conhecer a vida e a obra de Aldo Daniele Locatelli, inserindo e compreendendo a sua produção sacra no contexto da Modernidade no Brasil, e averiguar as razões que instigaram a Igreja Católica a contratar artistas estrangeiros para a decoração de seus templos foram os objetivos das primeiras pesquisas que realizei em torno dos objetos que compõem o cerne deste estudo.

O ano de 2008 marcou o início de um trabalho de buscas por informações sobre outro pintor italiano que não obteve o mesmo reconhecimento alcançado por Locatelli, apesar dos trabalhos decorativos "magníficos" que realizou em países como Viena e Budapeste -entre aspas, um dos tantos adjetivos à sua arte que constam em registros escritos por membros do clero e leigos que conviveram consigo, como o Núncio Apostólico Angelo Roncalli ${ }^{1}$ que, ainda durante a sua estada no país e dez anos após a sua chegada, se tornaria o Papa João XXIII (1958-1963)-. Emilio Sessa ${ }^{2}$ era o seu nome e sabe-se que ele foi companheiro de atelier, colega de estudos (em Bergamo, Itália) e tornou-se compadre de Locatelli, já no Rio Grande do Sul (Brasil), quando do nascimento de Fábio Sessa, seu filho benjamim. O conhecimento dos trabalhos produzidos por Sessa viria a reforçar ainda mais a ideia de que houve uma intenção diferenciada na inclusão de Locatelli à equipe que rumaria ao Brasil, pois a complementaridade entre as técnicas e os temas que cada um dos dois pintores elaborou é indiscutível. Cada ambiência contém um amplo conjunto de obras e a soma de todas elas formam espaços que contam vidas de santos, dogmas e preceitos fundamentais do catolicismo. 
As minhas primeiras pesquisas tencionavam compreender, é preciso citar, duas fases profissionais de um decorador e de um figurista, dois momentos ou realidades diferentes que eles viveram em seus países de origem e de destino (de uma Itália devastada pela Segunda Guerra a um Brasil em pleno desenvolvimento de suas cidades e cada vez mais promissor para o campo das Artes). Duas trajetórias que se entrelaçavam em torno de objetivos comuns e que, a cada novo trabalho, se tornavam indissociáveis. A trajetória profissional de Aldo Locatelli no Brasil -é possível afirmar, com base em diversas bibliografias sobre sua vida e sua obra (especialmente Cordoni, 2002; e Gomes, 1998) e nas comprovações obtidas em conversas com familiares seus e de Emilio Sessa- teve início quando Roncalli anunciou a Sessa que havia a necessidade de que fosse formado um grupo de pintores para tratativas a respeito da encomenda de uma nova ambiência no Rio Grande do Sul, em fins de 1947. Este artista reuniu-se com alguns de seus colegas de estudos da Escola de Artes Andrea Fantoni, a fim de estruturar a equipe que viajaria consigo para o Brasil sob o encargo de decorar a recentemente construída catedral São Francisco de Paula (Pelotas, RS). Entre os pintores escolhidos, estiveram presentes Adolfo Gardoni, Atilio Pisoni e Aldo Locatelli, e todos entenderam que era irrecusável este chamamento a rumar para um país onde as cidades se desenvolviam e "o campo da arte paulatinamente se consolidava" (Kern, In: Gomes, 2007, p. 74).

Cabe destacar, neste ínterim, que o tema ora apresentado configura-se na continuidade de uma pesquisa que teve seus desdobramentos pautados em questões relativas à importância patrimonial das obras produzidas por estes e por outros pintores, realizada no período de 2012 a 2014. A partir da observação de alguns painéis de Aldo Locatelli que compunham o cerne da minha dissertação de Mestrado pude notar, contando com as contribuições de pesquisadores mais experientes, que as cenas que remetem às vidas e aos exemplos de fé de alguns dos santos representados em ambiências sacras trazem aportes para uma análise ainda pouco explorada e totalmente nova para a historiografia brasileira: A das representações de santos missionários em pinturas sacras compostas por Aldo Locatelli em igrejas católicas do Rio Grande do Sul. Esta constatação resultou no meu atual projeto de doutorado em História, intitulado provisoriamente como A Pintura Sacra de Aldo Locatelli: Um estudo a partir das representações pictóricas de santos missionários na igreja Santa Teresinha do Menino Jesus de Porto Alegre e na catedral São Luiz Gonzaga de Novo Hamburgo. (Rio Grande do Sul, 1948-1962), já em andamento na Universidade do Vale do Rio dos Sinos (Unisinos, Brasil).

Num primeiro momento e, para fins de elaboração de uma metodologia de pesquisa pertinente a esta proposta, foi necessário fazer um levantamento sobre temas de imagens sacras em interiores de igrejas rio-grandenses, no qual se destacaram obras da igreja Santa Teresinha do Menino Jesus, de Porto Alegre (1952-1957) e da catedral São Luiz Gonzaga, de Novo Hamburgo (1959-1962). Entre os santos representados na igreja Santa Teresinha se encontram, além da sua padroeira, Santa Teresa D’Ávila -fundadora da Ordem dos Carmelitas Descalços- e São Francisco Xavier -que, com Santo Inácio de Loyola, foi um dos precursores da Ordem dos Jesuítas-, ambos, missionários atuantes no século XVI. Num breve cotejamento com a ambiência dedicada a São Luiz Gonzaga, estes painéis reportam a questionamentos acerca da importância conferida pela Igreja à perpetuação das memórias de homens e de mulheres que foram modelares ao catolicismo, tendo em vista 
as reproduções de passagens de suas vidas dispostas em cenas que preenchem paredes de diversos templos.

No que concerne ao estado da arte e à produção bibliográfica disponível acerca do legado artístico sacro de Aldo Locatelli, cabe salientar que este é um tema ainda não visitado por outros historiadores latino-americanos além de breves menções. Entre os autores que discorrem sobre a vida e a obra deste artista podem ser citados Luiz E. Brambatti (2008) -turismólogo e autor de um livro abrangente das ambiências produzidas pelo pintor no Brasil, contendo uma breve biografia, fotografias em alta definição e pequenas descrições das obras, notoriamente direcionado ao Turismo-, Eva Regina Coelho (2003) -organizadora de um encarte com descrições gerais de algumas pinturas de Locatelli no Estado, também dirigido ao Turismo, conforme a própria autora destaca- Margherita Cordoni (2002) autora de uma biografia densa do artista e das suas obras na Itália e no Brasil (publicada em Bergamo, em língua italiana), além de uma bibliografia farta em novas e possíveis referências-Paulo Gomes e Armindo Trevisan (1998) -cujo trabalho pode ser considerado, entre as produções brasileiras, como um dos mais completos em descrições e aprofundamentos sobre a vida e a obra de Locatelli. Da produção de Paulo Gomes destaca-se, ainda, o seu estudo Artes plásticas no Rio Grande do Sul: Uma panorâmica (2007) -coletânea de textos organizados pelo autor que apresenta uma contextualização sobre o desenvolvimento das artes no estado, abrangendo biografias de artistas plásticos que atuaram no RS e descrições de algumas de suas obras-, Renato Rosa e Decio Presser (1997) -organizadores de um dicionário de artes plásticas no Rio Grande do Sul, com dados biográficos sobre diversos artistas e destaque para algumas de suas produções em ordem cronológica-, $\mathrm{Ma}$ riza Simon Santos (1991) -com um artigo publicado no periódico O Continente sobre as pinturas de Aldo Locatelli e Emilio Sessa, onde são avultadas as técnicas utilizadas pelos pintores, além do contexto em que foram produzidas algumas das suas obras-, Altamir Moreira (2006) -com sua tese de Doutorado defendida no Instituto de Artes da Universidade Federal do Rio Grande do Sul (IA-UFRGS, Brasil), cuja metodologia de pesquisa parte de um levantamento geral e sintético das pinturas murais relacionadas à "morte e ao além" que foram produzidas ao longo do século XX em igrejas católicas da região central do RS, entre elas, a obra "Santidade de Santa Teresinha" (um dos painéis de Locatelli que integram a ambiência da igreja Santa Teresinha do Menino Jesus, pintado em 1957)-, Luciana de Oliveira (2011) -com sua dissertação de Mestrado defendida no Programa de Pós-Graduação em História da Pontifícia Universidade Católica do RS (PUCRS, Brasil), desenvolvida a partir de uma análise dos murais produzidos por Locatelli no Palácio Piratini (1951-1955), em Porto Alegre. Entre as pinturas destacados pela autora está o painel intitulado "Índio Missioneiro", que apresenta um índio sentado portando uma lança, em frente às ruínas de São Miguel, como parte do conjunto representativo da Formação histórico-etnográfica do povo rio-grandense.

Estas breves notas de pesquisa podem ser consideradas como o início da elaboração de um cenário em que estarão dispostos personagens, histórias e tempos desenhados ao revés. $\mathrm{O}$ contexto da Igreja, num Rio Grande do Sul que se encontrava em plena modernização de suas cidades, sobreleva memórias das missões através de iniciativas clericais consonantes ao aumento populacional e ao desenvolvimento urbano, bem como à valorização de um passado eclesiástico que reflete os resultados da evangelização de todos os povos pela supre- 
macia católica ocidental. Através da arte, passado e presente destacam intentos religiosos e institucionais que foram dados a ver pelos pinceis de artistas como Aldo Locatelli. Esta reflexão deverá permear a leitura das análises a seguir.

\section{Por um Rio Grande do Sul Missionário: Entendendo o contexto da Igreja e da Arte}

Com base na bibliografia disponível sobre a obra de Aldo Locatelli e nas pesquisas que já foram iniciadas a partir das fontes selecionadas para esta investigação (as imagens representativas de santos missionários), o início da década de 1950 foi definido como o momento introdutório da presente explanação, embora seja fundamental que se faça um breve retorno a 1948. Além de marcar a ocasião da vinda de Locatelli, Sessa e outros pintores à região sul do Brasil, cabe considerar, no eixo temático definido, que este foi um ano de intensa movimentação na Igreja Católica e de grandes mobilizações de fiéis em prol da evangelização missionária, incentivadas pelo clero ao longo de toda a década de 1940. Entre os principais eventos de 1948 estiveram a Terceira Semana Nacional de Ação Católica, ocorrida entre 24 e 26 de outubro -direcionada às famílias das zonas rurais- e o $\mathrm{V}$ Congresso Eucarístico Nacional ${ }^{3}$, que aconteceu de 28 a 31 de outubro, em Porto Alegre. Segundo Aldino Luiz Segala, o V Congresso foi "um momento em que multidões de fiéis foram movimentadas, além da intelectualidade católica e autoridades" (In: Bernardi, 2007, p. 59). É fundamental que os congressos eucarísticos sejam entendidos como aportes para muitos dos empreendimentos da Igreja ao longo do século XX, considerando que são destacados entre as mais importantes manifestações do catolicismo pela reafirmação da sua presença nos estados brasileiros frente ao crescente aumento populacional nas cidades e às ofertas constantes de outras religiões que se encontravam em contínua disputa por espaços. Segala considera, ainda, que além da realização do V Congresso "aconteceram [no mesmo ano] vários Congressos Eucarísticos Estaduais, como os de Porto Alegre, Caxias do Sul e Pelotas" (Ibidem, p. 60). É notório que, nos anos que se seguiram a estes eventos, muitas igrejas foram construídas e decoradas no Rio Grande do Sul e que, nessas três cidades, Locatelli pintou algumas das suas obras mais conhecidas.

Outro fato relevante sobre os antecedentes da vinda deste pintor ao Brasil foi a instabilidade que se abateu sobre a Europa do pós Segunda Guerra Mundial (1939-1945) quando, em contrapartida, os centros urbanos brasileiros tiveram um rápido aumento populacional e de mão-de-obra, expandindo significativamente a sua economia. Segundo Maria Lúcia Kern, este é um contexto em que as cidades do Rio Grande do Sul crescem e se modernizam e, então, "a população desfruta de maior acesso à educação e aos centros nacionais e internacionais, e suas modalidades de vida social se modificam” (In: Gomes, 2007, p. 74). O convite recebido pelos pintores italianos para viajar ao Brasil no final da década de 1940 foi, portanto, uma oportunidade irrecusável de melhores condições de vida e de trabalho, além de uma possibilidade mais segura para a subsistência de suas famílias.

Pouco tempo depois da contratação dos artistas bergamascos para a decoração da catedral de Pelotas, eles foram incumbidos de executar diversos outros trabalhos no Rio Grande do Sul, com temáticas nem sempre relacionadas à arte sacra -sobretudo Locatelli, que se 
destacou na feitura de pinturas murais em lugares de destaque em Porto Alegre, elaborados em conjunto com outros artistas ou solo. As suas obras ficaram conhecidas e repercutiram de tal modo que o artista foi convidado a trabalhar como professor no Instituto de Belas Artes desta cidade, que se encontrava em pleno desenvolvimento de sua grade programática e de contratação de docentes. Sobre a questão de a visibilidade de Locatelli ser, ainda hoje, maior do que a de Emilio Sessa e as de outros artistas com quem executou obras conjuntas, uma das hipóteses mais prováveis é, justamente, a de que ele gozava de maiores oportunidades para o estabelecimento de relações e articulações profissionais no campo das artes por estar vinculado ao ensino no Instituto que se tornou, reconhecidamente, um dos mais importantes locais de difusão artística no RS. Nessa conjuntura, a valorização da Arte Sacra também acontecia e passava a ser fortemente estimulada através do incentivo do clero católico. De acordo com Maria Helena Andrés (1966), o Papa João XXIII -justamente, o Núncio que convidou os pintores italianos a rumarem ao Brasil-, tendo assumido o pontificado no ano de 1958, foi um dos maiores entusiastas da inserção de programas artísticos nas igrejas. Segundo a autora, sobre a intervenção papal nas exposições artísticas e,

Sentindo, também, a necessidade de um entrosamento maior entre os artistas e a igreja, o Papa João XXIII procurou estimular a criação de uma arte sacra, capaz de representar em tôda a sua plenitude a época em que vivemos. Instituiu para isso prêmios nas exposições oficiais, visando estimular os artistas a realizarem obras de arte baseadas em temas religiosos (Andrés, 1966, p. 84).

Esta iniciativa de João XXIII de estimular os artistas, então voltados às grandes exposições e aprendizados de novas técnicas, à incorporação da Arte Sacra aos seus ofícios foi fundamental para a composição de sucessivas ambiências tematizadas no Sagrado. O Concílio Vaticano II, convocado por este papa em 1962, reforçaria ainda mais o seu legado. Mas, retomando o início de todo este processo -quando da feitura das obras de decoração da catedral de Pelotas-, é notável que a Igreja Católica empenhou-se na construção de novos templos no Rio Grande do Sul e em outros estados brasileiros passando a fomentar projetos decorativos para seus interiores com certa frequência. Porto Alegre se tornava "um polo de atração para a região sul do país ao oferecer oportunidades profissionais, passando assim por uma fase de crescimento demográfico e de êxodo rural" e, neste sentido, é indiscutível que "o campo de arte paulatinamente se consolidou" (Kern, In: Gomes, op. cit. p. 74). Com o rápido desenvolvimento urbano, as novas igrejas passavam até mesmo a dividir os espaços dos bairros com outras comunidades que já estavam em atividade, como foi o caso da paróquia Santa Teresinha do Menino Jesus, que contou com a colaboração do pároco da igreja São Pedro, Monsenhor Emílio Lottermann, para a organização das suas instalações e dos seus primeiros ritos. Lottermann mobilizou a comunidade da sua igreja a participar com obras e doações e então, segundo Élvio Vargas (2004), "apesar de ainda faltarem os vitrais, piso, forro e revestimento interno das paredes, o templo foi consagrado, iniciando as funções religiosas em 1949” (p. 91).

A história de construção e consolidação deste templo, um dos cenários principais sob o qual se desenrola a trama do presente estudo, pode ser compreendida junto às de diversas 
outras edificações que foram erigidas e ornadas em meados do século XX, num momento oportuno em que arquitetos, engenheiros e pintores -brasileiros e estrangeiros- ganhavam espaço para demonstrar suas habilidades e ofertar seus serviços em diferentes instâncias e lugares. Os artistas italianos que rumaram ao país no final da década de 1940, sob o convite do futuro Papa João XXIII, integraram-se rapidamente ao processo de abrangência doutrinária da Igreja Católica e passaram a disponibilizar sua mão-de-obra nas paróquias das quais tinham notícias de ainda haver ausência decorativa.

\section{Apresentando os personagens: Representações de tempos distantes}

Ao saber da existência de um novo templo católico em Porto Alegre, Emilio Sessa apresentou um projeto decorativo ao Monsenhor Atílio Fontana -vigário que estava em atividade na igreja Santa Teresinha-, onde se incluíam, além de uma proposta para a ornamentação geral, a disposição dos espaços a serem ocupados pelas pinturas murais do figurista Aldo Locatelli. Para a decisão e aprovação deste projeto, Fontana reuniu alguns membros do Apostolado da Oração ${ }^{7}$, entre outros paroquianos dispostos a formar uma comissão de arte sacra que, ao longo dos trabalhos, ficaria responsável pelos contatos com os pintores e pela observação do andamento das obras. Com a aprovação da proposta do pintor, ficou definido que a temática central da nova ambiência seria dedicada à vida e à fé da padroeira Santa Teresinha do Menino Jesus, que deveria ser representada a partir de cenas descritas em seus diários e em estudos sobre o seu legado religioso. Os momentos destacados por Locatelli seguem uma ordem cronológica que tem início sobre o altar, com o painel "Teresinha apontando seu nome inscrito no céu" (1952) baseado num episódio da infância de Teresa de Lisieux ${ }^{1}$ e segue em direção à porta de entrada, culminando na cena "Teresinha no leito de Morte" (1957). Dois destes painéis - "Santa Teresinha entre as crianças" e "Santa Teresinha, padroeira das missões" foram pintados, porém, nas laterais da cúpula defronte a abside -ambos, no ano de 1955-, destacando paralelamente a face evangelizadora e missionária da padroeira.

Observa-se com esta análise a importância que teve, para o catolicismo, a rememoração desta santa que viveu no século XIX nas paredes de uma igreja católica construída, decorada e atuante no século XX. A memória contada de momentos significativos da vida de Santa Teresinha do Menino Jesus pode ser lida através das imagens que a representam e, neste ínterim, é importante atentar para as palavras de Locatelli que foram destacadas no material de divulgação mais recente desta igreja, segundo o qual ele teria dito que "o homem não deveria se contentar em simplesmente olhar as coisas e, sim procurar descobrir e compreender o que há nas mesmas." E, indo um pouco mais além nesta reflexão, talvez seja possível inferir que a santa "padroeira das missões" evocou um sentimento de identidade, tanto no momento em que recebeu este desígnio, quanto no destaque que foi dado à sua memória. Pollak contribui com as palavras expressas pelo pintor ao concluir que,

Podemos, portanto, dizer que a memória é um elemento constituinte do sentimento de identidade, tanto individual como coletiva, na medida em que ela é também um fator extremamente importante do sentimento de continuidade e 
de coerência de uma pessoa ou de um grupo em sua reconstrução de si (Pollak, 1992, p. 215).

A partir das informações encontradas na documentação eclesiástica já analisada, fica compreensível que este era um objetivo claro da Igreja Católica: Incutir nos seus fiéis a curiosidade sobre as coisas sagradas e o sentimento de identidade religiosa, a tal ponto que a comunicação visual através de símbolos e cenas de vida de seus padroeiros servisse como estímulo para a sua permanência nas igrejas e para a evangelização fora de seus muros. Neste sentido, Leandro Karnal e Luiz Estavam Fernandes (2017) fazem uma análise demorada sobre o significado a posteriori que o imaginário sobre os santos possui para os católicos. Para estes historiadores,

O segredo dos santos está no cruzamento entre o divino e o humano. Suficientemente humanos para estarem ao meu lado e me entenderem. Suficientemente santos para estarem junto ao Criador e contemplá-lo. Humanos com a centelha do Espírito, mas almas que habitaram no invólucro da carne. São como eu, mas estão além de mim (Karnal e Fernandes, 2017, p. 12).

Parece que, em boa medida, este excerto traduz o sentido que a Igreja confere à rememoração de seus santos como modelos de fé e intercessores ao alto, pois, embora estejam distantes no tempo em relação àqueles que os cultuam, eles são dados a ver e, portanto, passíveis de se materializarem à sua frente através de recursos como a pintura. Para a elaboração das obras que narram momentos exemplares de suas vidas, chama atenção o cuidado e o estudo aprofundado do artista em fontes que estiveram diretamente relacionadas a eles. O painel de Aldo Locatelli sobre "a vida e a fé de Santa Teresinha" que a destaca como padroeira das Missões -desígnio que lhe foi atribuído pelo Papa Pio XI, em 14 de dezembro de 1927, mesmo dia em que foi beatificado o missionário jesuíta do século XVI Francisco Xavier- por exemplo, traduz em imagens as memórias impressas nas páginas dos seus diários, que foram publicados em diversos idiomas com a autorização da sua irmã Celina. Embora esta santa tenha manifestado interesse em trabalhar nas missões religiosas pelo mundo, sabe-se que Teresa nunca o fez, pois o Carmelo de Lisieux (França), ao qual era provisoriamente congregada, não realizava essa atividade. Um fato interessante sobre estes estudos é que na publicação de 1951 dos diários no Brasil, há uma sequência de fotografias cuja disposição dos personagens principais é muito semelhante às que foram, apenas um ano depois, adotadas por Locatelli em suas pinturas. A atualização do artista e de seus contratantes é inegável no que se refere aos temas reproduzidos. 


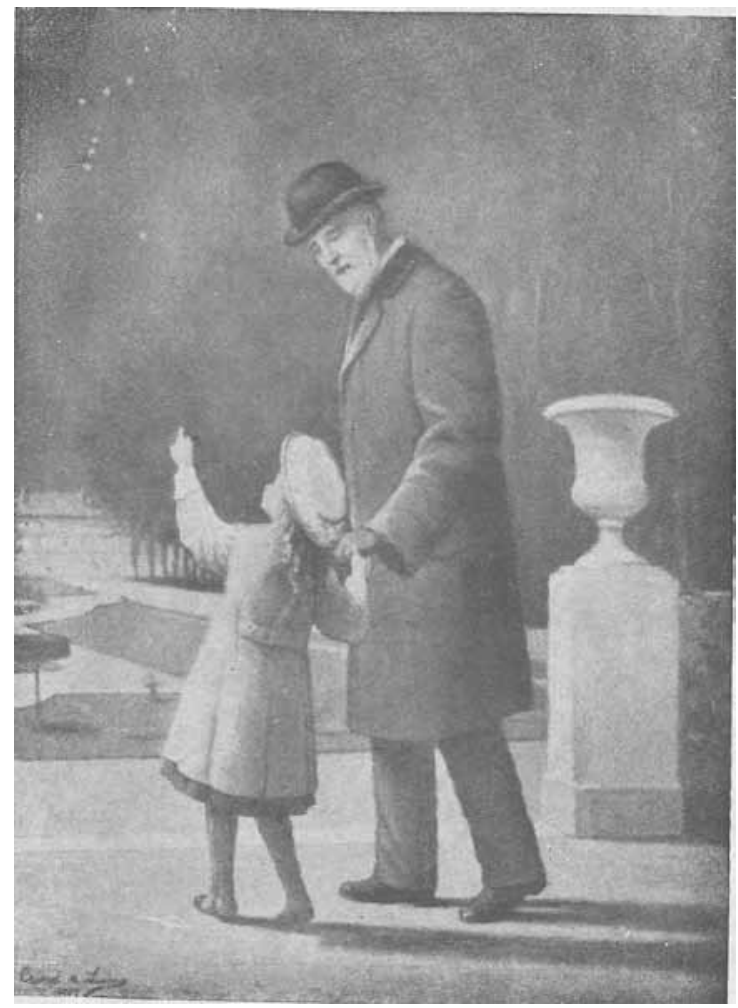

Imagem 1 (esquerda). Imagem de Teresinha apontando seu nome no céu. Fonte: Diário de Teresa do Menino Jesus, 1951.

Imagem 2 (abaixo). Pintura "Teresinha apontando seu nome inscrito no céu”. Aldo Locatelli, igreja Santa Teresinha do Menino Jesus. Porto Alegre, 1952. Fotografia: Aldo Toniazzo.

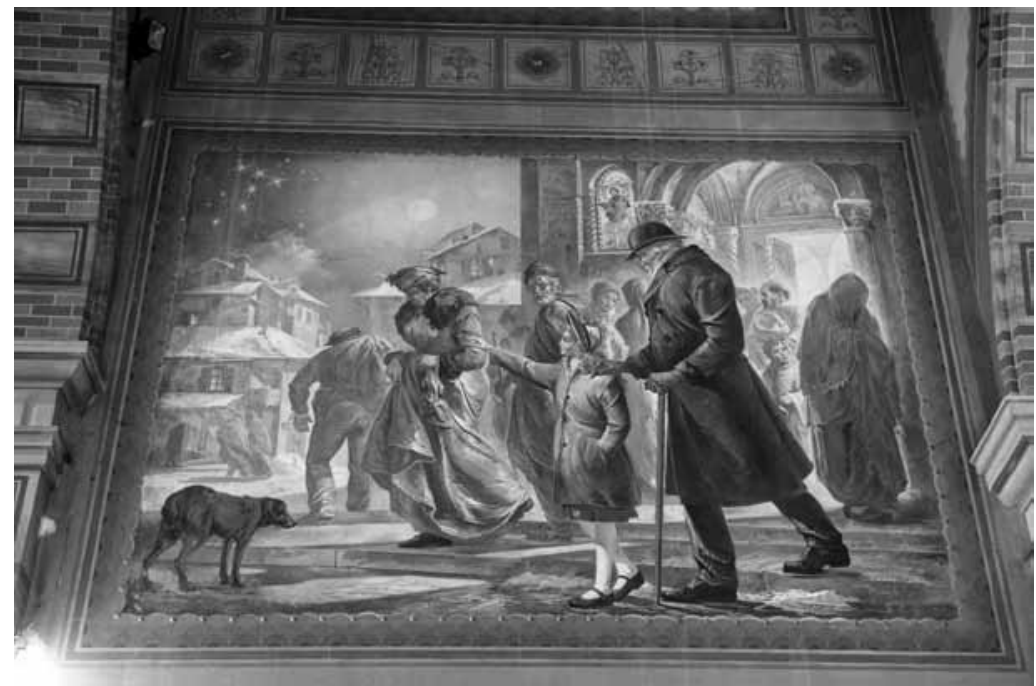


Além de as obras pictóricas narrarem circunstâncias do tempo em que viveram os santos que as protagonizam -no caso apresentado, a infância de Santa Teresinha-, o espectador da sua feitura e dos resultados do trabalho do artista também dialoga e empresta o seu próprio tempo, modificando-o desde a sua experiência visual. Em considerações introdutórias sobre os estudos das imagens, o historiador da arte Georges Didi-Huberman (2015) refere que "Sempre, diante da imagem, estamos diante do tempo" (Didi-Huberman, 2015, p. 15). E, na medida em que vai aprofundando as suas reflexões, a hipótese de que as intenções ou semelhanças de determinados sujeitos ou grupos do tempo presente -contemporâneos do observador- estão intrínsecas nos personagens, no cenário e, sobretudo, em temas que recorrem em lugares semelhantes é avultada. A respeito da compreensão das relações possíveis (e possibilitadas) entre sucessivas temporalidades nas representações -textuais e, neste caso, visuais- Reinhart Koselleck tece considerações fundamentais em seu livro (2011), entre as quais podemos destacar, em relação às diferentes fontes que podem ser utilizadas em pesquisas históricas que partem de leituras imagéticas, o seguinte parágrafo:

O problema da representação, isto é, da maneira como a história narra e descreve, remete, no campo do conhecimento, a diferentes dimensões temporais do movimento histórico. A constatação de que uma "história" já se encontra previamente configurada antes de tomar a forma de uma linguagem limita não só o potencial da representação como também exige do historiador que se volte necessariamente à fonte em busca de fatos. Esta contém indicadores de sucessão temporal muito diversos (Koselleck, 2011, p. 133).

Além da análise imagética, esta pesquisa também se pauta em fontes escritas, tais como livros de tombo das igrejas analisadas, jornais e boletins paroquiais, atas de grupos de oração e, ainda, em fontes orais relativas às comunidades, ao artista e à própria Igreja enquanto instituição que se manteve atuante na sociedade ao longo das décadas que se seguiram. Se, por um lado, a configuração prévia da história da Igreja pode ser analisada a partir das suas representações, por outro, o cotejamento das fontes quase sempre resulta num aprofundamento maior das circunstâncias em que se encontravam os seus agentes. Sob tal perspectiva, a realização de um cotejamento entre obras pictóricas do mesmo artista confere certa legitimação à história que se conta. A catedral São Luiz Gonzaga de Novo Hamburgo (localizada próxima a Porto Alegre) também foi lugar onde pincéis derem a ver exemplos de outrora.

Em tempos muito anteriores ao da vida de Teresinha de Lisieux, outro santo também descobriu, ainda na infância, a sua vocação missionária e, assim como ela, viria a tornar-se conhecido como um símbolo de pureza para os católicos ${ }^{11}$. São Luiz Gonzaga (15681591), nascido na Itália, foi um seguidor da Ordem de Inácio de Loyola e Francisco Xavier que precisou enfrentar grande resistência por parte da sua família -dona de feudos e possuidora de grande prestígio- para ingressar na Companhia de Jesus, "renunciando para sempre a seus direitos de herdeiro do principado, em favor do irmão menor" e assim, "com 19 anos, seguiu para Roma a fim de ingressar no noviciado dos jesuítas" (Conti, 1984, p. 267). Ao seu orago foram dedicadas muitas igrejas, dentre as brasileiras, a catedral São Luiz Gonzaga, de Novo Hamburgo, construída em 1926 (mesmo ano em que Pio XI o procla- 
ma "Padroeiro da Juventude Católica"12) que abriga obras pictóricas de Aldo Locatelli e Emilio Sessa, produzidas entre os anos de 1959 e 1962. Nesta igreja, coube a Locatelli a composição de cenas referentes à vida do seu padroeiro, da sua infância ao momento de sua morte (contaminado com tifo, aos 23 anos), numa apresentação semelhante à que foi feita na igreja Santa Teresinha do Menino Jesus, embora dispostas de forma diferente -todas, próximas ao altar-e, também, a pintura de uma via sacra. Segundo consta na resenha de Arthur Rabuske e Gastão Spohr (1977), sobre os acontecimentos do ano de 1959, “o renomado pintor Aldo Locatelli foi contratado para executar as pinturas que ornamentariam o presbitério. Muito feliz na escolha foi a comissão de construção, juntamente com o pároco" (p. 35).

No decorrer da realização das obras pictóricas na catedral São Luiz Gonzaga, convém lembrar que Ângelo Roncalli já atuava frente à Igreja como Papa (1958-1963) e que, conforme destacado, o então pontífice foi o responsável pela vinda de Sessa e Locatelli ao Brasil. Um dos principais legados do seu pontificado foi, indubitavelmente, o fato de que durante toda a sua atuação sacerdotal e pontifical ele "procurou estimular a criação de uma arte sacra, capaz de representar em toda a sua plenitude a época em que vivemos" (Andrés, 1966, p. 84). Ou, indo um pouco além, pode-se entender: A época que a Igreja Católica intencionava reviver através da "recristianização" da sociedade, conforme explica Arnoldo Doberstein (2002, p. 22-24), a exemplo do Concílio de Trento (século XVI), convocado no período de atuação dos primeiros santos missionários.

\section{Memórias das Missões em Imagens: A pintura sacra de Aldo Locatelli}

O processo de missionação tem sido objeto de estudos de pesquisadores de diversas áreas. Através de fontes e de perspectivas múltiplas, historiadores, antropólogos, etnólogos e outros profissionais têm se debruçado sobre questões atinentes ao catolicismo e aos recursos de que seus mentores e seguidores se valeram para comunicar os seus dogmas e preceitos, expandindo horizontes para além dos mares, das fronteiras e das mais profusas concepções sobre Deus e o paraíso celestial.

Em sua obra Testemunha ocular Peter Burke destaca a importância do observador das imagens, chamando atenção para a função de testemunha que ele poderá desempenhar quando as contempla atentamente, consciente de que o que vê pode ser uma evidência histórica significativa acerca dos tempos, lugares e sujeitos representados. Sobre isto, Burke explica que "embora os textos também ofereçam indícios valiosos, imagens constituem-se no melhor guia para o poder de representações visuais nas vidas religiosa e política de culturas passadas" (Burke, 2004, p. 17).

Considerar a pintura sacra de Aldo Locatelli como fonte principal de uma pesquisa em História é, sem dúvida, um desafio. Mas é, também, um exercício de leitura que tem como diferencial a necessidade de um aprofundamento na simbologia católico-cristã, na dogmática e, porque não dizer, no esforço de tentar compreender qual foi o alcance que este recurso teve nas comunidades nas quais foi introduzido. As respostas para esta questão ainda estão sendo buscadas, todavia, alguns autores já dão algumas pistas acerca da sua função pedagógica. Para Eduardo França Paiva (2006), 
As imagens traduziam as palavras sagradas e eram lidas como se fossem elas para os fiéis cristãos analfabetos. Por isso chamá-las, hoje, de pedagógicas, isto é, de representações que eram dadas a ler e que ensinavam, dogmaticamente, sobre a história, sobre os homens, sobre o mundo, sobre Deus e sobre o paraíso celestial (Paiva, 2006, p. 35).

Em palavras anteriores a estas, Paiva considera ainda que "Os contextos diferenciados dão significados e juízos diversos às imagens. O distanciamento no tempo entre o observador, o objeto de observação e o autor do objeto também imprime diferentes entendimentos, uma vez que as leituras são sempre realizadas no presente, em direção ao passado" (Paiva, 2006, p. 31). Para além das representações dos santos destacados como arquétipos da missionação católica, é fundamental relacioná-los às ordens religiosas das quais fizeram parte, uma vez que ambas são consideradas precursoras do processo de evangelização nos quatro continentes. Nos dois painéis selecionados para esta análise, os personagens em destaque são carmelitas ou jesuítas, havendo a presença de iniciadores (Santa Teresa D’Ávila e São Francisco Xavier) e seguidores exemplares (Santa Teresinha e São Luís Gonzaga).

Um breve estudo feito por Leandro Karnal intitulado A produção da memória: análise de um quadro jesuítico (In: Beired, 2010) traz uma abordagem em torno da questão da produção da memória a partir de imagens, tendo como objeto o quadro La conquista espiritual del Paraguay por medio de la música, pintado por Gonzalo Carrasco no início do século XIX. O autor considera que as imagens são produzidas a serviço da memória e, a partir da combinação dos elementos que comportam, buscam reforçar acontecimentos e personagens do passado. Em sua apreciação, "tanto as cartas como as imagens pertencem a um esforço de produzir uma memória que seja favorável ao empenho missionário jesuítico (...). O esforço é duplo: construir memória e associá-la a imagens claras, morais, didáticas e edificantes." (p. 557). Tendo como mote o enunciado de que as imagens comportam memórias, o cenário está montado para apresentar o sétimo painel de Locatelli na igreja Santa Teresinha do Menino Jesus de Porto Alegre, destacado a seguir. 


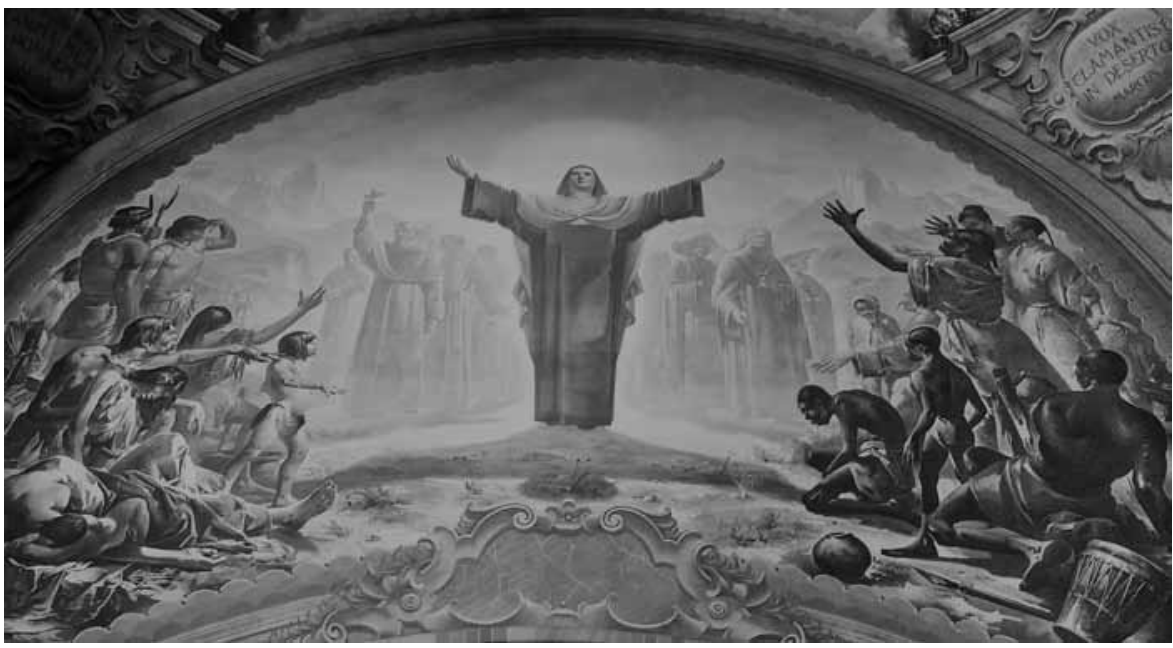

Imagem 3. Painel “Santa Teresinha, Padroeira das Missões”. Aldo Locatelli (1955). Fotografia: Aldo Toniazzo, 2013. Acervo da autora.

O painel em destaque apresenta a figura da santa padroeira ao centro, abrangendo a maior parte do espaço e tendo as mãos elevadas em sinal de oração e intercessão. Ao fundo, em tonalidades claras e esfumadas, passando a ideia de distanciamento temporal, estão representados religiosos missionários seguindo o jesuíta Francisco Xavier (à esquerda) e religiosas missionárias acompanhando a carmelita Santa Teresa D’Ávila (à direita). À frente do grupo de Xavier, indígenas magros e em claras posições de súplica parecem clamar à Santa Teresinha enquanto, à frente de Santa Teresa e das irmãs carmelitas, representantes asiáticos e africanos elevam suas mãos e seus olhares para o mesmo ponto central: A santa proclamada padroeira universal das missões, juntamente com Francisco Xavier (Cavalcante, 1997, p. 372).

Tendo em vista que Francisco Xavier (1506-1552) e Teresa D’Ávila (1515-1582) foram missionários atuantes no século XVI, enquanto Santa Teresinha viveu no século XIX, compreende-se o distanciamento estabelecido por Locatelli entre eles através de técnicas de coloração, luz e sombra. Observando a delimitação em três planos desta cena pode-se inferir, ainda, que há uma sugestão de afastamento "moral” entre os santos e os pagãos, relacionada à ideia de salvação. O conjunto da obra mostra, deste modo, uma representação da evangelização de todos os povos, afirmando a universalidade da Igreja Católica frente aos povos convertidos à sua doutrina.

A imagem de Santa Teresinha pode ser entendida como simbólica e remete à expansão da palavra de Deus, anteriormente disseminada por outros exemplos de cristãos que empre- 
enderam missões em todos os continentes, como foi o caso dos padres da Companhia de Jesus $^{13}$ e dos congregados da Ordem dos Carmelitas descalços ${ }^{1}$ que viriam a ser, pelos séculos seguintes, referências para a educação, tanto catequética quanto escolar. Aos jesuítas, por exemplo, são atribuídas construções e administrações de diversos espaços de ensino e de lazer para a juventude no RS e no Brasil.

A pintura de Santa Teresinha, sobretudo, no painel analisado, serve de pretexto para o estabelecimento de um diálogo entre três tempos: O século XVI, quando se deu a atuação dos primeiros missionários católicos; o século XIX, período da curta vida de Santa Teresinha; e o século XX, sendo o ápice para a sua veneração o momento em que o papa Pio XI a designou como "Padroeira das Missões" ao lado de Francisco Xavier, SJ. E os tempos se estenderiam além, chegando ao encontro da comunidade que receberia o conjunto pictórico produzido pelo figurista bergamasco.

Dois anos após a conclusão das obras na igreja Santa Teresinha do Menino Jesus, Aldo Locatelli e Emilio Sessa apresentaram-se para decorar outras ambiências sacras brasileiras. No RS, eles trabalharam juntos em mais algumas igrejas, como na catedral São Luiz Gonzaga de Novo Hamburgo (1959-62), bem como realizaram empreendimentos sozinhos ou em companhia de outros pintores. Foi nesse tempo que Locatelli fez algumas de suas obras de cavalete mais famosas e se dedicou a outros trabalhos não relativos a religiosidades.

A respeito das obras da catedral, o livro de Tombo apresenta as expectativas do padre e dos paroquianos, inscritas em um pequeno, porém, entusiasmado parágrafo no dia 11 de fevereiro de 1959, contando que,

Aos onze de fevereiro do corrente ano, veio o Seu Aldo Locatelli, afamado pintor, apresentando o projeto dos painéis que ornarão o presbitério. A comissão faz questão de deixar o presbitério ou a capela-mór quanto mais belo possível, porque esta é realmente a casa de Deus.

Ad maiorem Dei gloriam -ou, "para a maior glória de Deus", numa saudação frequentemente utilizada em missivas e cumprimentos trocados entre os membros da SJ-, Locatelli conseguiu concluir, mesmo com vários outros trabalhos, as representações de São Luiz, deixando poucos detalhes inacabados quando precisou afastar-se definitivamente dos andaimes por motivos de saúde que logo o levaram a óbito.

Não se pode deixar de observar que as aproximações biográficas e, ao mesmo tempo, o distanciamento temporal existentes entre São Luiz Gonzaga e Santa Teresinha são, em grande medida, instigantes para uma pesquisa que objetiva compreender, entre outras questões, como a Igreja (re)produziu os seus discursos através de imagens ao longo dos séculos. É preciso mencionar, mesmo brevemente, um pouco do que já foi levantado até então sobre a trajetória de vida e de rememoração de São Luiz.

Partindo de informações escritas por teólogos e clérigos, sabe-se que houve um santo no século XVI -entre tantos- que também havia descoberto na infância a sua vocação missionária e que se tornaria conhecido, à semelhança de Santa Teresinha, como um símbolo de pureza para os católicos. São Luiz Gonzaga (1568-1591), nascido na Itália, foi um jovem admirador das ações empreendidas pela Ordem de Inácio de Loyola e Francisco Xavier e que precisou enfrentar forte resistência por parte da sua família, que era dona de feudos e 
possuidora de grande prestígio -sendo seu pai o então Marquês e comandante do exército de Castiglione (Itália) - para ingressar na Companhia de Jesus, "renunciando para sempre a seus direitos de herdeiro do principado, em favor do irmão menor". Então, "com 17 anos, seguiu para Roma decidido a ingressar no noviciado dos jesuítas” (Conti, 1984, p. 267).

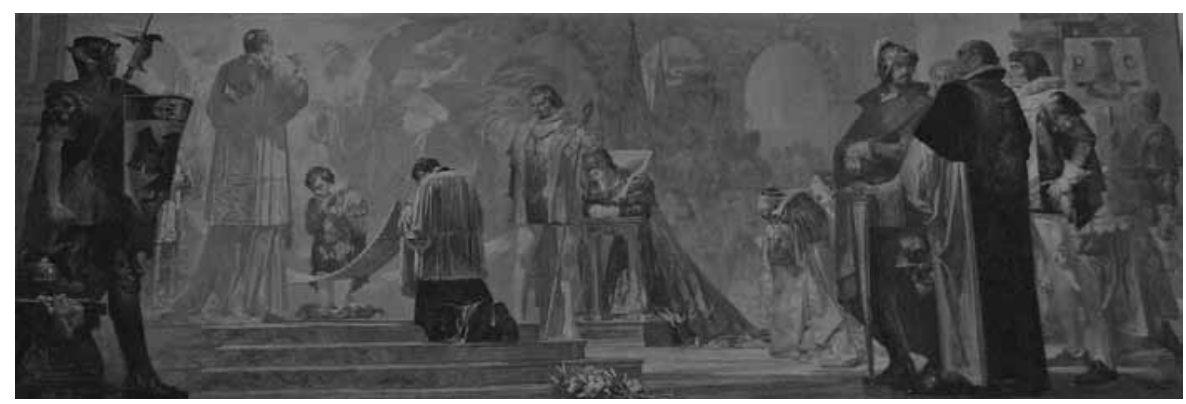

Imagem 4. Painel sobre a consagração de Luiz Gonzaga à SJ e a abdicação dos seus direitos em favor do irmão menor. Aldo Locatelli (1959). Fotografia e acervo da autora, 2016.

Nesta cena, o espaço se divide em, pelo menos, três planos que contam sobre o momento de renúncia de Luiz à herança familiar para ingressar na SJ. Este é o primeiro ato (à esquerda), seguido pela presença de dois personagens da sua história: Seu pai -de pé, num provável sinal de reprovação à escolha do filho, uma vez que, segundo Conti (1984), ele desaprovava esta decisão- e sua mãe, a grande incentivadora que tivera em sua vocação. Logo atrás de outras figuras ajoelhadas durante a sagração (à direita), estão presentes integrantes das postulações mais altas exército de Castiglione e, ao fundo, um soldado. Semelhantemente ao outro painel analisado, Locatelli utiliza técnicas de luz, sombra e proporções para conferir um distanciamento entre o primeiro e o segundo plano. Mas há uma diferença elementar no que tange às temporalidades representadas: No painel "Santa Teresinha, Padroeira das Missões", o plano de fundo é o lugar dedicado aos santos que antecederam a padroeira em sua vida missionária. Já nesta obra, o plano que aparece distante remete ao futuro, quando Luiz Gonzaga atravessaria os muros do mosteiro e iniciaria a sua pretensa vida sacerdotal, caso tivesse a sorte de viver para cumprir seus votos.

\section{Considerações Finais}

Assim como referido por Peter Burke (2004) acerca da função testemunhal das imagens, também o pesquisador que tem o tempo como mediador de seus trabalhos é testemunha 
ocular dos avanços que estudos como este puderam alcançar na segunda metade do século XX. São diversas as possibilidades que podem ser "desbravadas" em meio a uma gama cada vez maior de recursos visuais, textuais e contextuais e foi com base nisto que o presente artigo foi organizado, considerando que as pinturas sacras de Aldo Locatelli nas igrejas do Rio Grande do Sul, produzidas entre 1952 e 1962, traduzem discursos eclesiásticos que permearam os sucessivos processos de afirmação religiosa da Igreja, através de comunicações simbólicas estabelecidas pelo ato de fazer olhar para paredes. Antes, elas eram vazias de tintas e de significados. Depois, passaram a ser preenchida por formas, cores e representações repletas de intencionalidades.

Em pleno processo de modernização dos centros urbanos brasileiros e de iniciativas diversas do clero católico para a afirmação dos seus preceitos perante a sociedade, dotar os espaços de culto com figuras exemplares do catolicismo e contratar profissionais advindos do centro da Igreja para produzi-las foi, sem dúvida, uma estratégia que repercutiu para além dos muros paroquiais. Comprova-se isto pela ativa participação que Locatelli teve na dinâmica social, acadêmica e pública das cidades por onde passou, considerando que a realização de obras sacras representou para ele o princípio de uma sucessão de oportunidades de trabalho, inclusive, como professor no Instituto de Artes da maior cidade do RS. Embora se encontre ainda em seu tempo de elaboração, esta pesquisa possibilitou a identificação de discursos que podem ser reforçados pelos textos escritos por membros da Igreja sobre um mesmo objetivo: A evangelização e a educação missionária. Além disto, é facilmente perceptível que há semelhanças estéticas e formais na organização das cenas representadas, criando recursos de aproximação entre obra e observador.

No painel "Santa Teresinha, Padroeira das Missões", percebe-se que foram estabelecidas ligações discursivas entre três momentos: O século XIX, quando Santa Teresinha viveu; o século XVI, identificado pelas figuras dos missionários São Francisco Xavier SJ e Santa Teresa D'Ávila, fundadora da OCD, e o observador católico do século XX, incentivado a evangelizar em todos os lugares possíveis. Num curto espaço de tempo houve, ainda, a dedicação de outra igreja do RS ao orago de um santo jesuíta do século XVI, cuja história de fé, de vida e de morte também dá continuidade e reforça a mensagem missionária junto à juventude cristã.

Aldo Locatelli faleceu no ano de 1962, justamente, no auge da valorização da Arte Sacra. Os discursos dos Papas João XXIII e Paulo VI proferidos durante o Concílio Vaticano II (1962-65) remetem, em diversos trechos, ao Concílio de Trento do século XVI, contudo, tal como Locatelli, Ângelo Roncalli também não pôde acompanhar a finalização do seu empreendimento, pois veio a óbito no ano seguinte. Não há dúvidas, todavia, de que o convite feito aos pintores italianos em 1948 e as ações que reforçam a importância da Arte para a Igreja e para as cidades se constituíram em um reconhecido legado religioso e artístico para o Brasil. Os estudos sobre estas imagens ainda requerem certo esforço e passam para o estágio de "tempo para a sistematização de ideias e para elaborações textuais" que possam, ainda provisoriamente, auxiliar nas reflexões em torno dos seus significados e dos recursos necessários para que sejam dadas a ver a um público maior. Toda pesquisa requer tempo... 


\section{Notas}

1. Angelo Roncalli foi, conforme citado, um grande incentivador da vinda de Emilio Sessa e de Aldo Locatelli ao Brasil e, posteriormente, na condição de papa e sob a denominação pontifícia de João XXIII, empreendeu diversas iniciativas em prol da valorização da Arte Sacra e da realização de obras artísticas em igrejas brasileiras. Os anos do seu pontificado (1958-1963) abrangem o período final da nossa análise, portanto, nele se inicia e praticamente se encerra o recorte temporal deste artigo. Sobre o papa João XXIII, há maiores informações na biografia escrita por Thomas Cahill (2002); no livro de Daniel Rops (1962), que abrange o período anterior e inicial do Concílio Vaticano II; nas suas encíclicas, que compõem diversas publicações da Igreja, como o tomo intitulado Documentos de João XXIII (1998) e que, também, integram o site http://alexandriacatolica.blogspot.com.br, entre diversas outras referências.

2. Pesquisas sobre Emilio Sessa têm sido desenvolvidas, desde 2008, pelo Instituto Cultural Emilio Sessa (ICES), contando com a colaboração de profissionais das áreas da História, do Turismo, da Arquitetura e das Artes Plásticas. Parte da produção do instituto consta no site http://www.emiliosessa.com.br e nos livros Doberstein (Org.). (2012) e Doberstein (Org.). (2014), sendo estas fontes consideradas atuais, também, para os estudos sobre a produção de Locatelli na Itália e no Brasil.

3. Chamo atenção para o V Congresso Eucarístico Nacional por se tratar de um acontecimento de grandes proporções ocorrido em 1948, amplamente divulgado pela imprensa católica, como o jornal Estrela do Sul e a revista Unitas, da diocese de Porto Alegre. A resenha histórica escrita por Arthur Rabuske (S.J.) e Gastão Spohr (1977) sobre a paróquia São Luiz Gonzaga, de Novo Hamburgo cita este evento como "uma semana de intenso trabalho e estudos" (p. 32). Entender as formas como a Igreja se articulava entre os meios religioso e social, observar as suas ações e, também, os discursos do clero veiculados pela mídia é fundamental para compreender o contexto da vinda de Aldo Locatelli e de outros artistas sacros ao Rio Grande do Sul.

4. Embora esta análise tenha início num período anterior ao delimitado para este texto, a temática das disputas religiosas no Brasil pode ser entendida a partir da tese de Doutorado em História de Marta Rosa Borin (UNISINOS, 2010).

5. As igrejas que contêm obras de Locatelli em Porto Alegre são: Igreja Santa Teresinha do Menino Jesus (1952-1957) -entre as pinturas deste local está o painel "Santa Teresinha, Padroeira das Missões”, que integra o objeto analisado neste artigo-, Igreja Nossa Senhora de Lourdes (1960-1962) -onde há três painéis que retratam a aparição da sua padroeira e o Sagrado Coração de Jesus, pintada concomitantemente à realização das obras da catedral de Novo Hamburgo, sobre a qual, também, teço considerações. Estes foram os últimos trabalhos realizados por Locatelli, tendo sido um deles concluído após a sua morte (1962), pelo artista espanhol José Sicart -, e Catedral Metropolitana Nossa Senhora Madre de Deus (1957) -que possui apenas um painel de Locatelli, produzido no mesmo ano do término da sua intervenção na ambiência da igreja Santa Teresinha do Menino Jesus, cujo tema é uma representação de anjos reverenciando a imagem de Nossa Senhora-. Em Caxias do Sul, a Igreja de São Pelegrino (1956) tornou-se famosa por abrigar a via sacra de Locatelli, com elementos impactantes - desde a expressividade das suas figuras e cores, até os objetos 
que integram a sua composição -características presentes em muitas das suas obras-. Em Pelotas, a Catedral São Francisco de Paula (1948) foi a primeira igreja brasileira a receber os trabalhos sacros de Aldo Locatelli, que ficou encarregado de produzir os afrescos do seu teto.

6. Este projeto ainda não foi encontrado, mas a sua existência foi comprovada através da entrevista cedida a membros do ICES pelo padre Nelson Selbach -vigário auxiliar na igreja Santa Teresinha do Menino Jesus, quando da feitura das obras-, em 24 de outubro de 2010.

7. O Apostolado da Oração (AO) é um grupo iniciado por missionários jesuítas, que teve sua origem na França, no final do século XIX, com o objetivo de evangelizar e propagar o catolicismo. No Brasil, suas atividades iniciaram em São Paulo (1871), por iniciativa do padre Bartolomeu Taddei, SJ. e, a partir de então, seus membros passaram a atuar em praticamente todas as igrejas católicas brasileiras, na sua maioria, as ligadas à Companhia de Jesus. Na catedral São Luiz Gonzaga, componente deste estudo, o grupo está em atividade desde a fundação paroquial. Fontes: Rabuske, 1977; http://www.apostoladodaoracao.com.br

8. As comissões de arte sacra são grupos formados por membros paroquiais cuja função é acompanhar os trabalhos artísticos inseridos nas igrejas, desde as primeiras tratativas. Está entre os meus objetivos de pesquisa contatar membros desses grupos -neste caso, das igrejas Santa Teresinha do Menino Jesus e São Luiz Gonzaga- a fim de coletar informações que poderão ser úteis para a compreensão do período estudado. Sobre as suas normas, ver o domínio: http://comissaoartesacra.org.br (site da Comissão de Arte Sacra da Arquidiocese de Porto Alegre).

9. Santa Teresinha (Thérèse Martin, 1873-1897) escreveu diários desde a sua infância, transcorrida em Alençon (França), onde registrava as suas vivências e aspirações à vida religiosa. Um ano após sua morte, esses diários foram disponibilizados por sua irmã e transcritos para diversos idiomas com o título História de uma alma: escritos autobiográficos. As edições ora referenciadas foram publicadas pela editora Paulus (1986) e pelas Edições Carmelo (2005). Sobre a vida de Santa Teresinha, também há obras como o dicionário organizado por Pedro Teixeira Cavalcante (1997) e os livros de Orlando Gambi (1997) e M. M. Philipon (1958), que integram o referencial bibliográfico deste estudo.

10. Lisieux é a cidade francesa onde se situa o convento em que Teresa Martin, aos quinze anos de idade, fez os seus votos como noviça. É recorrente aparecer, em estudos sobre ela, o seu nome relacionado a esta localidade. É importante referir previamente que há outras menções a esta santa, a começar pelo diminutivo "Teresinha" que, além de fazer alusão ao fato de ela ter se dedicado à religiosidade desde a infância e falecido com apenas vinte e quatro anos, também -e principalmente-, a distingue de Santa Teresa D’Ávila, igualmente citada como Santa Teresa de [do Menino] Jesus. Entre os atributos de Santa Teresinha que podem aparecer junto ao seu nome estão das Rosas - relacionado à promessa feita (em seus diários) de que, após sua morte, faria cair na terra uma chuva de rosas (ou milagres) -e da Sagrada Face - numa associação à "Oração da Santa Face para Pecadores", escrita por Teresinha na sua juventude.

11. São Luiz Gonzaga é conhecido no catolicismo como um dos Três Lírios da Companhia, atributo que lhe é concedido como um símbolo de pureza e de pertencimento à Ordem de Jesus (simbolizado, em muitas composições e em passagens bíblicas, por esta flor). 
Segundo consta no artigo de Cesar Augusto T Silva (2013) sobre este desígnio, "devido às suas curtas vidas dedicadas aos estudos na Companhia de Jesus, Estanislau Kostka (15501568), Luiz Gonzaga (1568-1591) e João Berchmans (1599-1621) se tornaram conhecidos como os santos jesuítas protetores dos jovens estudantes" (p. 10). Esses três santos são, geralmente, citados juntos como os Três Lírios da Companhia e, sobre eles, há maiores detalhes no Compêndio da vida de Santo Estanislau Kostka, São Luiz Gonzaga e São João Berchmans (1940), editado e publicado pela Igreja Católica.

12. Assim como Santa Teresinha foi proclamada por Pio XI, em 1927, "Padroeira Universal das Missões", um ano antes o mesmo papa atribuiu a São Luiz Gonzaga o predicativo de "Padroeiro da Juventude Católica", conforme consta em sua Carta Apostólica assinada em 13 de junho de 1926. Esta carta encontra-se no banco de dados do Vaticano e pode ser acessada pelo domínio: http://w2.vatican.va/content/pius-xi/it/apost_letters/documents/ hf_p-xi_apl_19260613_singulare-illud.html

13. A Companhia de Jesus é definida por José Carlos Sebe (1982) como uma "Ordem atrelada aos princípios da burguesia expansionista, pois comprometida com a colonização e o missionarismo" (Sebe, 1982, p. 8). Segundo este autor, a fundação da SJ ocorreu no período colonial (século XVI) e os seus campos de atuação abrangeram o Oriente -principalmente, a Ásia- e a América -em especial, o Brasil-, embora seus membros tenham atuado, também, na América espanhola.

14. A Ordem dos Carmelitas Descalços é uma congregação que se divide em grupos femininos (irmãs) e masculinos (frades), fundada no século XVI por Santa Teresa D’Ávila e São João da Cruz. Assim como Santa Teresinha -e, provavelmente, servindo-lhe como inspiração-, a fundadora da OCD deixou diversos escritos, o que contribuiu para que the fosse atribuído o desígnio de "doutora da igreja" pelo papa Paulo VI (1970). No livro de Sebe (1982) -já citado como um referencial sobre a SJ-, a OCD é mencionada em alguns trechos, como o que informa que se trata da primeira congregação feminina benquista pela Igreja, e que "teve grande aceitação entre o povo português" (Sebe. 1982, p. 48).

\section{Bibliografia}

Andrés, M. H. (1966). Vivência e arte. Rio de Janeiro: Agir.

Beired, J. L.; Capelatto, M. H. e Prado, M. L. (Orgs.). (2010). Intercâmbios políticos e mediações culturais nas Américas. Assis: FCL - Assis - UNESP Publicações - FFLCH - USP. Bernardi, J. (Org.). (2007). História e missão da igreja no RS. Porto Alegre: EST Edições.

Borin, M. R. (2010). Por um Brasil católico. Tensões e conflitos no campo religioso da República. Tese de Doutorado em História. São Leopoldo: UNISINOS.

Brambatti, L. E. (2008). Locatelli no Brasil. Caxias do Sul: Belas letras.

Burke, P. (2004). Testemunha ocular. História e imagem. Bauru, SP: EDUSC.

Burke, P. (2011). A escrita da história. Novas perspectivas. São Paulo: Unesp.

Cahill, T. (2002). Papa João XXIII. Rio de Janeiro: Objetiva.

Cavalcante, P. T. (1997). Dicionário de Santa Teresinha. São Paulo: Paulus.

Coelho, E. R. B. (2003). Uma viagem pelos caminhos de Aldo Locatelli. Santa Maria: Gráf. Pozzatti. 
Compêndio da Vida de Santo Estanislau Kostka, São Luiz Gonzaga e São João Berchmans. (1940). Porto Alegre, Selbach.

Conti, D. S. (1984). O santo do dia. Santa Maria: Pallotti.

Cordoni, M. (2002). Aldo Locatelli, Il mestiere di pittore. Bergamo: Comune di Villa D'Almè, Corponove Editrice.

Didi-Huberman, G. (2017). Diante do tempo. História da Arte e anacronismo das imagens. Belo Horizonte: Editora UFMG.

Doberstein, A. W. (2002). Estatuários, catolicismo e gauchismo. Porto Alegre: EDIPUCRS.

Doberstein, A. W. (Org.). (2012). Emilio Sessa, pintor. Primeiros tempos. Porto Alegre: Gastal \& Gastal.

Doberstein, A. W. (Org.). (2014). Emilio Sessa, pintor. Tempos intermediários. Porto Alegre: Gastal \& Gastal.

Gambi, O. (1997). Vida de Santa Teresinha. São Paulo: Santuário.

Gomes, P. e Trevisan, A. (1998). Aldo Locatelli. O mago das cores. Porto Alegre: Marprom - Assessoria de Marketing, Relações Públicas e Promoções / Companhia Estadual de Energia Elétrica.

Gomes, P. (Org.). (2007). Artes plásticas no Rio Grande do Sul. Uma panorâmica. Porto Alegre: Lahtu Sensu.

Karnal, L. e Fernandes, L. E. O. (2017). Santos fortes. Raízes do sagrado no Brasil. Rio de Janeiro: Anfiteatro.

Koselleck, R. (2011). Futuro passado. Contribuição à semântica dos tempos históricos. Rio de Janeiro: Contraponto. Ed. PUC-Rio.

Moreira, A. (2006). A morte e o além. Iconografia da pintura mural religiosa da região central do Rio Grande do Sul (século XX). Tese de Doutorado em Artes Visuais. Porto Alegre: UFRGS.

Oliveira, L. C. (2011). O Rio Grande do Sul de Aldo Locatelli. Arte, historiografia e memória regional nos murais do Palácio Piratini. Dissertação de Mestrado em História. Porto Alegre: PUCRS.

Paiva, E. F. (2006). História \& imagens. Belo Horizonte: Autêntica.

Papa João XXIII (1958-1963). (1998). Igreja Católica. Documentos de João XXIII. São Paulo: Paulus.

Philipon, M. M. (1958). Santa Teresinha de Lisieux. Um caminho todo novo. Rio de Janeiro: Olímpica.

Pollak, M. (1992). Memória e identidade social. In: Revista Estudos Históricos. Rio de Janeiro: FGV, vol. 5, n. 10.

Rabuske, A. (S. J.); Spohr, G. (1977). Resenha histórica da paróquia São Luiz Gonzaga de Novo Hamburgo (1926-1975). Novo Hamburgo: Encarte da paróquia s/ed.

Rops Daniel. (1962). Vaticano II. O concílio de João XXIII. Porto: Tavares Martins.

Rosa, R. e Presser, D. (1997). Dicionário de Artes Plásticas no Rio Grande do Sul. Porto Alegre: Ed. Universidade / UFRGS.

Santos, M. S. (1991). As obras de Locatelli e Sessa. (artigo). O Continente, ano II, janeiro de 1991.p. 10.

Sebe, J. C. (1982). Os jesuitas. São Paulo: Brasiliense. 
Silva, C. A. T. (2013). Arquitetura, iconografia e devoção. a igreja de Santo Inácio e Nossa Senhora das Vitórias da cidade do Rio de Janeiro. (artigo). XXVII Simpósio Nacional de História - UFRN. Natal, Anais do Simpósio.

Teresa do Menino Jesus, S. (1951). História de uma alma. Manuscritos autobiográficos. São Paulo: Paulus.

Teresa do Menino Jesus e da Santa Face. (2005). História de uma alma. Manuscritos autobiográficos. Coimbra, Portugal: Edições Carmelo.

Vargas, E. (2004). Torres da Província. História e iconografia das igrejas de Porto Alegre. Porto Alegre: Palotti.

\section{Referências eletrônicas:}

http://alexandriacatolica.blogspot.com.br

http://www.apostoladodaoracao.com.br

http://comissaoartesacra.org.br

http://www.emiliosessa.com.br

http://www.pcf.va

Resumen: Al desembarcar en Brasil en 1948, el muralista italiano Aldo Daniele Locatelli trajo consigo más que un visado histórico de formación en la célebre Escuela de Artes Andrea Fantoni: Sus pinturas en iglesias europeas ya proyectaban su fama, despertando el interés de altos exponentes del clero católico. Se puede afirmar, sin embargo, que aún no hay estudios publicados acerca de ese pintor que se profundicen significativamente en las temáticas reproducidas en iglesias de Rio Grande do Sul, donde está la mayor profusión de sus obras sacras. Las pinturas tematizadas en las misiones católicas del siglo XVI y en personajes destacados por su actuación en ese período o por una evangelización a posteriori concatenada a sus preceptos justifican el abordaje de ese artículo, desde un análisis temático y técnico que refleja el contexto de ejecución de dos murales integrantes del emplazamiento de la iglesia Santa Teresinha do Menino Jesus de Porto Alegre (1952-1957) y de la catedral São Luiz Gonzaga de Novo Hamburgo (1950-1962). Al considerarlas como fuentes, las imágenes dejan de tener función meramente ilustrativa y pasan a componer parte del corpus documental de una investigación. De acuerdo con esa premisa, Ivan Gaskell considera que "algunos historiadores vienen proporcionando valiosas contribuciones a nuestra visión del pasado usando las imágenes de una forma sofisticada y específicamente histórica" (GASKELL, 2011). Es en ese sentido que las imágenes representativas de Santa Teresa D’Ávila, San Francisco Xavier, San Luiz Gonzaga y Santa Teresita del Niño Jesús permiten una reflexión acerca de la importancia que el catolicismo brindó a la perpetuación de las memorias de religiosos misioneros por medio de las artes visuales.

Palabras clave: Aldo Locatelli - Pintura Sacra - Catolicismo - Memoria - Santos Misioneros. 


\begin{abstract}
When disembarking in Brazil in 1948, italian muralist Aldo Daniele Locatelli brought with him more than a historical view from an education in the renowned Escola de Artes Andrea Fantoni: His paintings in European churches already projected his fame, awakening the interest of high exponents of the Catholic clergy. It can be said, however, that there are no published studies about this painter that contain a significant deepening of the themes reproduced in churches in Rio Grande do Sul, where the largest profusion of his sacred works are found. The paintings with the themes of the Catholic missions from the $16^{\text {th }}$ Century and of characters highlighted by their actions in this period, or by an $a$ posteriori evangelization connected to its precepts, are what characterizes the approach of this article, in a thematic and technical analysis that reflects the context of the making of two murals integral to the ambience of the Santa Teresinha do Menino Jesus de Porto Alegre church (1952-1957) and of the São Luiz Gonzaga de Novo Hamburgo cathedral (1959-1962). When considered sources, the images no longer possess a merely illustrative function and become part of the documental corpus of a research study. In accordance to this premise, Ivan Gaskell considers that "some historians have provided valuable contributions to our view of the past using images in a sophisticated and especially historical way". (GASKELL, 2011). It is in this sense that the representative images of Saint Therese D’Ávila, Saint Francisco Xavier, Saint Luiz Gonzaga and Saint Therese of the Infant Jesus allow for reflection about the importance that Catholicism attributed to the perpetuation of the memories of religious missionaries through the visual arts.
\end{abstract}

Keywords: Aldo Locatelli - Sacred Painting - Catholicism - Memory - Missionary Saints.

[Las traducciones de los abstracts fueron supervisadas por el autor de cada artículo] 